museums serving the coastal area are in extremely poor circumstances, and generally have only a director or curator, who cannot possibly be an expert in all branches of natural history. There are not uncommon fishes in the sea which to any of the latter would appear as strange as, if not stranger than, a coelacanthid. It was the energy and determination of Miss Latimer which saved so much, and scientific workers have good cause to be grateful. The genus Latimeria stands as my tribute.

\title{
Science at the Royal Academy, I939
}

$\mathrm{T}$

HE one hundred and seventy-first exhibition of the Royal Academy of Arts, which opened on May 1, may be described as conservative artistically, although many will regard it as dull. Whatever trends in art it may reveal, it is remarkable in that it reflects nothing of the alarms and excursions, of political events almost unparalleled, of the clash of arms and the clatter of armoured vehicles that dominated the period in which the painting was done. In the exhibition there are more Elizabethan men-at-arms on one picture than there are modern soldiers in the thousand other works. There is one interior that contains a gasmask, and, surprisingly, only two or three pictures of refugees.

Few will grieve at this eclipse of war even if only on canvas; but the neglect of belligerent science extends also to the other branches almost as much, and, of the thirteen hundred pictures on show, only about one hundred can be said to include any features of scientific interest and that even in the widest possible sense. Of the nine or ten branches of science which one may allege to be represented, botany and geology appear to be the most favoured.

Agriculture is fortunate in being depicted in two of the finest works in the Academy. "Harvest", by Dame Laura Knight, R.A., with its sunchequered scene, and James Bateman's "Haytime in the Cotswolds", one of the pleasantest landscapes of the year.

Antiquaries have not far to seek for interest, because the second picture in the first room is "Antiquity", by Alan Beeton, A.R.A. This shows a human skull surrounded by palæoliths and resting upon a copy of Antiquity. The work is rather small, but this is compensated by the very large panel, destined for Brighton Grammar School, entitled "Hollingbury Camp, 1929", by Louis Ginnett, in which a party of archæologists is seen at work in the field. The anthropologists are better served, numerically, with a dozen pictures of much interest and considerable artistic distinction. Dame Laura Knight again heads the list with "Gipsy Family", a typically brilliant study which is certain to be acclaimed as one of the pictures of the year. Negro studies are unusually prominent, of which "The Dance, Zululand" (218), "Zulu Woman" (271) and "Zulu Exodus" (278) should be mentioned. A. R. Thomson's "Prince Kessie of Ashanti" and Neville Lewis's "Pondo Youth" are interesting portraits. A more comprehensive work is "The Village in the Jungle", by David Paynter, with a man, a woman and a child in the foreground. In addition there are a study of a Jamaican, Japanese and Chinese portraits, and the delightful Burmese "Ma Seyn Nu", by Gerald Kelly, R.A.

For the botanists, there are a profusion of titles and a riot of colour. Apple blossom, carnations, celery, cinerarias, chrysanthemums, gladioli, lilies, marguerites, roses, tulips and even tobacco flowers (these last by Dod Procter) are only a selection of the delights available. There are also surprises, such as the unexpected "Ilex Tree", a Montallegro landscape by Gerald Kelly. Gilbert Spencer's "Cherry Tree in Winter" and Sallis Benney's "Beech Trees" are other arboreal attractions. There are flowers under their own names, flowers as "Still Life", "Rainbow Colours", "Purity", or just "Flowers". Mr. C. R. W. Nevinson's "Autumn bouquet", and Sir George Clausen's "Roses" are noteworthy, while Miss Grace English contributes a charming variety of colour contrasts in her "Summer Flowers".

Perhaps the most attractive of what may be termed the botanical works is Charles Oppenheimer's "Galloway Woodlands in February". This is a large picture with a background of typical rolling Galloway scenery. The woodland, the picture's main feature, is carpeted with snowdrops and the whole effect makes a charming picture one would like to possess.

Botanical and geological interests are combined in Malcolm Milne's "Val Fleuri", where the gay alpine flowers decorate the high valley. The other pictures which may interest the geologist cover various aspects of the science. Antony Ayrton's "Alpine Landscape" and Hilda Carline's "A Welsh Farm" illustrate a variety of mountain scenery 
which is supplemented by the stark but ominous grandeur of "Tulloch, Inverness-shire", by Oliver Hall, R.A. Less rugged aspects of the British countryside are portrayed by Charles Oppenheimer in "The Red Roofs of Whitby", by Miss Amy Browning in "East Anglia" with its very characteristic landscape, and particularly in J. MeI. Patrick's quiet "Glamis Village". More informative geologically are Gerald Kelly's "River Lugno from Montallegro" with its clearly-shown valley forms, and Stephen Denison's "Lime Works at Wharfedale" with a quarry section. Sidney Lee, R.A., portrays varieties of bedding, an anticline and other folds, faulting and weathering in "The Road by the Cliff". The meander of a stream is well illustrated in "Pastoral" by George Henry, R.A.

Typical and pleasant coastal, cliff and rock scenery is shown by William Matthews in "Tantallon", by Julius Olsson, R.A., in "Rocks, Antibes", and by A. Raine Barker's "Bridport".

Applied geology is not forgotten, for there are a quarry in Kent (588), the sandpit, Coldharbour (233), and "Cement Works in Surrey", by G. W. Leech. The last picture reveals that the industrial activity is less disturbing æsthetically than might be imagined.

Geologists, geographers and all Americans will be interested by Norman Wilkinson's "San Salvador". In this bay, Columbus landed on October 21, 1492.

If the mineralogists have but two pictures assigned to them, they may be reminded that quality is sometimes better than quantity. In any event, Gerald Brockhurst, R.A., is responsible for the two pictures, both of which are characteristically exquisite portraits. In the first, "Mrs. Hubert Raphael" is portrayed wearing scintillating emeralds and diamonds, while in the second, a portrait entitled "Mrs. Harrison", the amethystine brilliance of necklet, brooch, bracelet and ring is striking and attractive and reveals the masterly skill of the artist in his medium.

The zoologists have been served not quite so lavishly as might have been expected. Mr. Munnings has, however, made his usual and appealing testimonies to equine grace. Miss Winifred Austen, in one of the very few dry points, portrays equine leisure. There are dogs and cats in oils, greyhounds in wash and in bronze, and an antelope in wood. Mrs. Lilian Andrews contributes a swan and family in pastel, and Philip Connard, R.A., shows "Flying Swans", a piece of much distinction. Mrs. Daisy Smith has a delicate water-colour study of kookaburras.

The zoo aspect is supplied by "The Birdhouse" by Percy Shakespeare, with its toucans and para- keets, and "Elephant in Regent's Park" by Henry Carr. "An August Evening in Suffolk", by Bertram Priestman, R.A., with its black-and-white cows, is peaceful ; Mr. John Platt's "Bull across the Path", a colour woodcut, is more aggressive.

The march of time in applied science is amply demonstrated by Sir Muirhead Bone's impression in chalk "Building the Queen Elizabeth" and Charles Cundall's detailed picture of the launch of the same vessel. The launch of the Mauretania is the subject of a wood-engraving by Marjorie Biscomb. The less spectacular sides of industry are represented by "Tin Miners" (383) and "Coke Ovens" (437). The march of science is depicted in "Television Rehearsal" by Harry Rutherford; "Chelsea Power Station" by Gerald Ackermann, and, in a different sense, in "Pylons", where Miss Evelyn Saner shows the feet of the pylons embedded in beautiful highland scenery.

The architecture section contains plans of much interest to many men of science. The new science buildings of the University of Oxford (1046), new or recent buildings of the University of London (1047), the Imperial College of Science (1082) and research laboratories at Berkhamsted (1079) are a few on exhibition.

Portraits of scientific men are not numerous, but the few are well worthy of note. There are Charles Wheeler's bronze bust of Col. W. A. Bristow and the marble bust of the late Sir Robert Mond by William King. Lord McGowan and Lord Weir are the subjects of splendid portraits by Harold Knight, R.A., and T. C. Dugdale, A.R.A., respectively. Malcolm Osborne, R.A., provides a dry point of Prof. Alexander Low, of Aberdeen, while an attractively academic portrait is Edward Halliday's painting of Prof. W. E. S. Turner. Others known in scientific and university circles who are portrayed include John Murray, principal of the University College of the South-West, Exeter (oil painting by R. G. Eves); Dr. A. W. Pickard-Cambridge, vice-chancellor in $1930-38$ of the University of Sheffield (oil painting by George Harcourt); Sir William Elderton (oil painting by Harold Knight); the late Dr. A. C. Woolner, vice-chancellor of the University of the Panjab, Lahore (statue by Gilbert Ledward); and the late Lord Moynihan (bust by Sir W. Reid Dick).

If for any reason these aspects of science should prove of little attraction, or should they pall, it may be comforting to know that the Academy also bears testimony to another science, an applied science which is, one believes, still also a pure science, that the month of May particularly welcomes. It is brilliantly dealt with in No. 264, Mr. Charles Cundall's "Test Match at Lord's".

W. E. Swinton. 